NBER WORKING PAPER SERIES

THE EFFECT OF ALLOWANCE ALLOCATIONS ON CAP-AND-TRADE SYSTEM
PERFORMANCE
Robert W. Hahn
Robert N. Stavins
Working Paper 15854
http://www.nber.org/papers/w15854

NATIONAL BUREAU OF ECONOMIC RESEARCH

1050 Massachusetts Avenue

Cambridge, MA 02138

March 2010

The views expressed herein are those of the authors and do not necessarily reflect the views of the National Bureau of Economic Research.

NBER working papers are circulated for discussion and comment purposes. They have not been peerreviewed or been subject to the review by the NBER Board of Directors that accompanies official NBER publications.

(C) 2010 by Robert W. Hahn and Robert N. Stavins. All rights reserved. Short sections of text, not to exceed two paragraphs, may be quoted without explicit permission provided that full credit, including (C) notice, is given to the source. 
The Effect of Allowance Allocations on Cap-and-Trade System Performance

Robert W. Hahn and Robert N. Stavins

NBER Working Paper No. 15854

March 2010

JEL No. H11,L51,Q58

\begin{abstract}
$\underline{\text { ABSTRACT }}$
We examine an implication of the "Coase Theorem" which has had an important impact both on environmental economics and on public policy in the environmental domain. Under certain conditions, the market equilibrium in a cap-and-trade system will be cost-effective and independent of the initial allocation of tradable rights. That is, the overall cost of achieving a given aggregate emission reduction will be minimized, and the final allocation of permits will be independent of the initial allocation. We call this the independence property. This property is very important because it allows equity and efficiency concerns to be separated in a relatively straightforward manner. In particular, the property means that the government can establish the overall pollution-reduction goal for a cap-and-trade system by setting the cap, and leave it up to the legislature - such as the U.S. Congress - to construct a constituency in support of the program by allocating the allowances to various interests without affecting either the environmental performance of the system or its aggregate social costs. Our primary objective in this paper is to examine the conditions under which the independence property is likely to hold - both in theory and in practice. A number of factors can call the independence property into question theoretically, including market power, transaction costs, non-cost-minimizing behavior, and conditional allowance allocations. We find that, in practice, there is support for the independence property in some, but not all cap-and-trade applications.
\end{abstract}

Robert W. Hahn

AEI

1150 17th St., NW

Washington, DC 20036

JCenterDir@aei.org

Robert N. Stavins

JFK School of Government

Harvard University

79 JFK Street

Cambridge, MA 02138

and NBER

robert_stavins@harvard.edu 


\title{
The Effect of Allowance Allocations on CAP-AND-Trade System Performance
}

\author{
Robert W. Hahn and Robert N. Stavins*
}

\section{Introduction}

This year - the fiftieth anniversary of the publication of "The Problem of Social Cost" (Coase 1960) - is an appropriate time to examine a key implication of that landmark study, which is of great importance not only for economics but for public policy as well. Our starting point is a well-known result from that article, namely that bilateral negotiation between the generator and recipient of an externality will lead to the same efficient outcome regardless of the initial assignment of property rights, in the absence of transaction costs, income effects, and third-party impacts. This result, or a variation of it, has come to be known as the "Coase Theorem."1

We focus on an idea that is closely related to the Coase Theorem, namely that the market equilibrium in a cap-and-trade system will be cost-effective ${ }^{2}$ and independent of the initial allocation of tradable rights (typically referred to as permits or allowances). That is, the overall cost of achieving a given emission reduction will be minimized, and the final allocation of permits will be independent of the initial allocation, under certain conditions. We call this the independence property.

We are interested in the independence property because of its great political importance. It is a key reason that cap-and-trade systems have been employed and have evolved as the preferred instrument in a variety of environmental policy settings.

Our primary objective is to examine the conditions under which the independence property is likely to hold. Our analysis is limited to environmental cap-and-trade systems, where the government specifies an overall level of pollution, distributes allowances corresponding to that level, and allows those allowances to be traded. ${ }^{3}$ Furthermore, we examine only the consequences of

\footnotetext{
*Hahn is Tesco Professor of Economics and Director of the Sustainable Consumption Institute, University of Manchester, Senior Visiting Fellow, Smith School of Enterprise and the Environment, University of Oxford, and Senior Fellow at the Georgetown Center for Business and Public Policy; and Stavins is the Albert Pratt Professor of Business and Government at the John F. Kennedy School of Government, Harvard University, University Fellow of Resources for the Future, and Research Associate of the National Bureau of Economic Research. The authors benefitted from comments by participants at "Markets, Firms and Property Rights: A Celebration of the Research of Ronald Coase," University of Chicago Law School, December, 2009, in particular, Thomas Hazlett. We also are grateful for helpful comments provided by Dallas Burtraw, Carolyn Fischer, Denny Ellerman, Suzi Kerr, Matti Liski, Juan-Pablo Montero, Sheila Olmstead, Tom Tietenberg, and Alistair Ulph. We thank James Sigel for truly superb research assistance. All remaining errors are our own.

${ }^{1}$ As Hazlett (2009) has noted, Coase was primarily concerned with the importance of transaction costs, not a world of zero transaction costs. It was Stigler (1988) who dubbed the above result the "Coase Theorem.”

${ }^{2}$ Cost-effectiveness refers to achieving an overall emissions objective at the lowest cost.

${ }^{3}$ We do not consider systems that primarily involve “offsets,” where a firm can generate emission credits from a baseline
} 
alternative free allocations of allowances, not the impacts of free allocations versus auctioning of allowances, a topic that has received much attention from economists (Goulder and Parry 2008).

In section 2, we examine the theory behind the independence property, starting with the key findings from partial and general equilibrium analyses. Then, in Section 3, we turn our attention to an assessment of the conditions under which independence can be expected to break down, including: transaction costs; uncertainty; conditional allowance allocations; market power, noncost-minimizing behavior by firms; and differential regulatory treatment of firms.

Section 4 starts with an empirical assessment of the independence property in existing capand-trade systems: lead trading; CFCs under the Montreal Protocol; the $\mathrm{SO}_{2}$ allowance trading program; the Regional Clean Air Incentives Market (RECLAIM) in Southern California; eastern $\mathrm{NO}_{\mathrm{X}}$ markets; the European Union Emission Trading Scheme (EU ETS); Article 17 of the Kyoto Protocol; and the Regional Greenhouse Gas Initiative. The section continues with an empirical assessment of anticipated independence in planned and proposed cap-and-trade systems: changes in the EU ETS; the New Zealand Emissions Trading Scheme, the Australian cap-and-trade system, and the American Clean Energy and Security Act (HR 2454). Section 5 concludes.

\section{The Fundamentals of Cap-and-Trade}

For some 40 years prior to Coase (1960), the sole economic response to the problem of externalities was that the externality in question should be taxed. In principle, a regulator could ensure that emitters would internalize the damages they fostered by charging a tax on each unit of pollution equal to the marginal social damages at the efficient level of pollution (Pigou 1920). Any quantity of aggregate emissions could be achieved cost-effectively through an appropriate emissions tax, because such a tax would make it in the interest of each emitter to equate the tax to its own (increasing) marginal abatement cost, with the result that marginal abatement costs would thereby be equated among emitters, achieving the necessary condition for cost-effectiveness. Whenever abatement costs differ across emitters (a ubiquitous fact of the real world), conventional, so-called "command-and-control" pollution policies - such as uniform performance standards and technology standards - would not be cost-effective, but a uniform Pigouvian tax would be.

Despite the theoretical merits of Pigouvian taxes, they have rarely been used, for a number of reasons. First, it is difficult to identify the appropriate tax rate, because decision makers typically do not have good information on benefits and costs. Second, political problems are introduced by the distributional consequences of Pigouvian taxes for regulated sources. Despite the fact that such systems minimize aggregate social costs, these systems may be more costly than comparable command-and-control instruments for regulated firms. This is because with the tax approach, firms pay both their abatement costs and taxes on their residual emissions (Buchanan and Tullock 1975). In practice, some of these costs will be passed on to consumers, but many firms may still be worse off under a tax.

Following Coase (1960), it became possible to think about solving the problem of pollution as one of clarifying poorly defined property rights. If resources such as clean air and water could be

that is not always well defined. While many of the cap-and-trade systems we examine allow for offsetting of pollution from sources outside of the cap-and-trade system, we do not focus on this relatively minor aspect of these regimes. 
recognized as a form of property, whose corresponding rights could be traded in a market, private actors could allocate the use of this property in a cost-effective way. Crocker (1966) and Dales (1968) each proposed a system of transferable discharge permits that could provide such a market solution: the regulator need only designate the total quantity of emissions allowed (the cap), distribute rights corresponding to this total, and allow individual sources of emissions to trade the permits until an optimal allocation had been reached.

In theory, the final allocation of the permits (and therefore the location of emissions) would not depend upon the initial allocation. This was implicit in the work of both Dales and Crocker, because such independence follows directly from the notion that by properly defining property rights, participating firms have incentives to exploit all potential gains from trade. In such a wellfunctioning market, the permit price itself will not be affected by the initial distribution of permits, because the initial allocation does not affect firms' marginal abatement cost functions. Therefore, the final allocation of permits, in which no firm can be made better off by buying or selling a permit at the market price, is unaffected. Montgomery (1972) rigorously proved that transferable permits would in theory achieve a cost-effective allocation of control responsibility, and would do so independent of the initial allocation of permits. ${ }^{4}$ Following Montgomery, this result was frequently cited and extended to other contexts (Tietenberg 1985).

This independence property is of central political importance and is an essential reason why cap-and-trade systems have been employed in representative democracies, where distributional issues may be of paramount importance in mustering support for a policy. In principle, the government can set the overall emissions cap - whether on the basis of economic efficiency or, more likely, some other grounds - and then leave it up to the legislature to allocate the available number of allowances among sources (locations) to build a constituency of support for the initiative without reducing the system's environmental performance or driving up its cost. ${ }^{5}$

Experience has validated the political importance of this property. For example, in the Senate debate over the Clean Air Act Amendments of 1990, "bonus allowances” were awarded to electricity generators in Ohio, which were going to incur particularly high costs because of their reliance on high-sulfur coal (Joskow and Schmalensee 1998; Stavins 1998); the result was the key support of Senator John Glenn (D-Ohio) for the legislation. This pattern should be contrasted with most public policy proposals - environmental or otherwise - for which the normal course of events is that the political machinations that are necessary to develop sufficient legislative support reduce the effectiveness of the policy and/or drive up its costs.

\section{Conditions Affecting the Independence Property}

We consider six conditions under which the independence property may - in principle break down in a cap-and-trade system: transaction costs; market power; uncertainty; conditional

\footnotetext{
${ }^{4}$ In particular, Montgomery (1972) showed that a cap-and-trade system defined in terms of ambient air quality at many receptor points would exhibit the independence property. Subsequent research demonstrated the independence property for a system of emissions permits (Krupnick et al. 1983).

${ }^{5}$ The choice of an environmental goal and the choice of a particular policy instrument for achieving that goal may be connected, and likewise it is possible that the choice of the cap of a cap-and-trade system may be connected with the choice of a specific allocation.
} 
allowance allocations; non-cost-minimizing behavior by firms; and differential regulatory treatment of firms.

\subsection{Transaction Costs}

Transaction costs arise from the exchange - not production - of goods and services, and are ubiquitous in market economies because parties to transactions must find one another, communicate, and exchange information. There may be a necessity to inspect and measure goods to be transferred, draw up contracts, consult with lawyers or other experts, and transfer title. There are three major sources of transaction costs in cap-and-trade markets: (1) search and information; (2) bargaining and reaching a decision; and (3) monitoring and enforcement. ${ }^{6}$

The first source, search and information, may be the most obvious. Due to the public-good nature of some information, it can be underprovided by markets. Brokers may step in to provide information about firms' pollution-control options and potential trading partners, and thus reduce transaction costs. Although less obvious, the second source of transaction costs, bargaining and reaching a decision, is potentially as important. There are real resource costs to a firm involved in entering into negotiations, including time and/or fees for brokerage, legal, and insurance services. The third source of transaction costs - monitoring and enforcement - can also be significant, but these costs are typically borne by the responsible governmental authority and not by trading partners, and hence do not fall within the notion of transaction costs incurred by firms.

Transaction costs can lead to a violation of the independence property. Coase's original formulation noted that the outcome of bilateral negotiation in the presence of transaction costs is affected by the identity of the exclusive property-right recipient. But is the outcome independent of the initial allocation when the quantity of allocation to a source changes? This is the key question for cap-and-trade systems.

The answer is that the effect of transaction costs on the independence of the final allocation from the initial permit allocation depends on the nature of the transaction costs present. If marginal transaction costs are constant, the final allocation of allowances is independent of the initial distribution (Stavins 1995) (apart from the limited sense discussed above, that is, the identification of an exclusive property-right recipient). ${ }^{7}$

In the case of increasing marginal transaction costs, independence does not hold. Under such conditions, as the initial allocation of allowances to a source is increased, its equilibrium control level will be reduced, thus increasing the departure of the post-trading equilibrium outcome from the cost-effective outcome. However, increasing marginal transactions costs are unlikely to be an important case in practice, because such costs are unsustainable: parties would simply split their transactions into smaller trades to economize. ${ }^{8}$

\footnotetext{
${ }^{6}$ All three sources can be thought of as representing cost due to lack of information (Dahlman 1979).

${ }^{7}$ Montero (1998) observes that this result does not hold if firms' marginal cost functions are discontinuous, as they might be if a firm is choosing among discrete technologies. In such cases, the existence of constant marginal transaction costs may preclude independence.

${ }^{8}$ Liski (2001) notes that the notion that increasing marginal transaction costs are unsustainable is based on the assumption
} 
Finally, under decreasing marginal transaction costs, a theoretically important case, independence does not hold. Such transaction costs might result where brokers offer quantity discounts on their services, or where there are positive information externalities at the market level. In this case, a shift in the allowance allocation away from the cost-effective equilibrium leads to a post-trading outcome that is closer than otherwise to the cost-effective equilibrium (Stavins 1995). This counterintuitive result is due to the fact that decreasing marginal transaction costs mean that there are scale economies of trading of which firms can take advantage. These theoretical results have been supported with experimental evidence from a laboratory study (Cason and Gangadharan, 2003). ${ }^{9}$

\subsection{Market Power and Market Structure}

The presence of market power in the allowance market of a firm under a cap-and-trade regime can prevent the final allocation of permits from being independent of the initial distribution. If the firm with market power is a likely allowance seller, it has an incentive to act as a monopolist and hold back allowances from the market to drive up allowances prices, ${ }^{10}$ and if it is a likely allowance buyer, it has an incentive to act as a monopsonist and buy fewer allowances to keep the price low (Hahn 1984). ${ }^{11}$ Because trading behavior depends critically upon the initial allocation, independence does not hold, and cost-effectiveness is not achieved.

These results hold in the case of multiple dominant firms acting as Cournot players (Westskog 1996), and in a market with few buyer and sellers, all of which have some ability to set prices (Malueg and Yates 2009). ${ }^{12}$ In both cases, the permit market achieves the cost-effective allocation only if the dominant firms initially receive the number of permits that leave them with no incentive to trade. ${ }^{13}$

that contacting new trading partners is costless. Increasing marginal transaction costs are sustainable if they are combined with sufficient fixed transaction costs between parties.

${ }^{9}$ If transaction costs are a function of market size - which is plausible if a thicker market results in lower costs of gathering information and greater opportunity for brokers to reduce friction in the market - then independence only holds if the pre-trade allocation of permits is significantly different from the cost-effective allocation (Liski 2001).

${ }^{10}$ Malik (2002) has shown that this dominant firm may actually choose to hold more permits than it needs, retiring the excess permits without their being used.

${ }^{11}$ According to Liski and Montero (2009), the independence property is not at risk in a dynamic permit market where firms can bank allowances, if the large players in the market are on the buyer side. These large buyers cannot exercise market power, because they suffer from a durable-goods monopoly problem, that is, they cannot credibly commit to keep a gap between their marginal costs and the allowance price.

${ }^{12}$ Malueg and Yates (2009) also examine a market in which participants have market power and private information; the result is that the ultimate allocation is less predictable, but the final allocation of permits remains a function of the initial distribution.

${ }^{13}$ Other variations of these basic models have been examined. Malik (2002) expands on Hahn (1984) to consider what would happen if some price-taking firms are noncompliant and suffer a penalty for noncompliance. This creates greater elasticity of demand for permits, which reduces the extent to which the dominant firm can profit from its market power. Still, the cost-effective allocation is not achieved, because the dominant firm continues to exercise some market power, and because noncompliant price-taking firms fail to equate their marginal abatement costs with the allowance price. 
The interaction of the permit market with a product market complicates the influence of market power on the final allocation of permits. For example, a dominant firm may utilize its power in the permit market to gain an advantage in its product market (Misiolek and Elder 1989), and thereby can manipulate the price of emissions permits to drive up the production costs of its rivals by forcing them to purchase less-cost-effective abatement technology. In this case, the dominant firm would tend to purchase more permits (or sell less) than it would in the case where there was no exclusionary effect in the product market.

Thus, where the dominant firm receives no permits, and is a buyer on the permit market, the final distribution of permits may be closer to the efficient allocation than would obtain in a competitive market. But if the dominant firm receives a disproportionately large share of permits and is a seller, then the degree to which market power leads the ultimate allocation to depart from the cost-effective allocation is exacerbated. ${ }^{14}$ On the other hand, if the dominant firms exercise market power only in the product market and not the permit market, the final allocation of permits will be independent of the initial allocation, but this allocation may not be cost-effective. ${ }^{15}$

Market structure can be important in other ways. One interesting case is imperfections in capital markets that cause firms to face liquidity constraints. In this case, initial allowance allocations may affect the ultimate allocation of permits. Liquidity constraints may be one reason why smaller firms tend to adopt new technologies more slowly (Saloner and Sheppard 1995). More broadly, lack of liquidity can prevent firms from being able to minimize costs by investing in either permits or abatement technology. A firm initially allocated a relatively large number of permits will have greater liquidity, in the form of readily-salable permits. Thus, allocation can affect entry and exit behavior.

\subsection{Uncertainty}

Uncertainty regarding future allowance prices can lead to violation of the independence property under two conditions: risk aversion on the part of regulated firms, and limits to transferability of allowances (transaction costs). The consequences are that firms with small initial allocations tend to over-invest in abatement technology in order to hedge against possible high future allowance prices, and firms with large initial allocations tend to under-invest in abatement technology in order to hedge against possible low future allowance prices (Badlursson and von dehr

\footnotetext{
Schwartz (2007) demonstrates that if permits are defined in terms of air quality space at a number of different receptor points with a different market pertaining to each receptor point, then, even with one or more dominant firms, the final allocation of permits may be independent of the initial allocation if the number of firms equals the number of markets in the ambient permit system.

${ }^{14}$ Eshel (2005) has extended this model to encompass a firm that has market power in both the permit and product markets, finding similar results.

${ }^{15}$ This is because rival firms engaging in Cournot competition may be more aggressive in the output market if they have higher marginal abatement costs (and will therefore buy permits), but may decrease output production if they are more efficient (and will therefore sell permits). In equilibrium, the less efficient firms will hold a larger share of emissions permits than would be welfare maximizing (Malueg 1990, Sartzetakis 2004).
} 
Fehr 2004). ${ }^{16}$ Laboratory experiments have provided some empirical support for these results (Betz and Gunnthorsdottir 2009).

Note that independence is affected only if there is some limitation on transferability. Otherwise, an appropriate price for the permits that incorporated their uncertain future value would emerge, and, absent other market imperfections, the market would clear so that the post-trading allocation of allowances would be independent of the initial distribution.

Another way in which uncertainty may affect the final allocation of permits is also related to transaction costs. Building off Stavins (1995), Montero (1998) incorporates uncertainty regarding whether a transaction, once initiated and in which costs have been sunk, can be completed. The results are similar to those described by Stavins (1995), but with uncertainty increasing the extent to which the final equilibrium will depart from the cost-effective one. Essentially, uncertainty increases the degree to which transaction costs impede mutually-beneficial trades.

More broadly, if such uncertainty is endogenous, and is a function of the number of permits demanded and the effort spent to attain trade approval, then for all types of transaction costs constant, increasing, and decreasing - the tendency will be for an initial allocation further away from the least-cost equilibrium to increase the departure of the ultimate allocation from the ideal one (Montero 1998). This result contrasts with Stavins (1995), who found that, under decreasing marginal transaction costs, economies of scale would lead an initial allocation further from the leastcost one to result in a more cost-effective ultimate allocation.

\subsection{Conditional Allowance Allocations}

Although conditional allowance allocations do not strictly fit within the realm of the independence property because the government determines an allocation rule and not a specific allocation, this is an important case of where the initial allocation affects the outcome. For example, the government may assign allowances based on a measure of output (for example, gasoline production or electricity output) in the previous period. ${ }^{17}$ We consider these rules because they determine the initial allocation, and because they are proposed in a variety of applications.

This output-based updating allocation rule serves as a production subsidy (Fischer 2001), which affects the post-trading allocation, and thus can affect efficiency. Firms can be anticipated to increase production, because they can receive more permits in the subsequent period, which contributes to their profits. The emissions price drives reductions in emissions intensity, but the prospect of allocations for additional production offsets (in part or in full) the prospect of additional costs from the emissions embodied in that production. Output-based allocation therefore means that emissions-intensive products have lower marginal costs than under ordinary free allocations, in which the full value of the embodied emissions would be embedded in the firm's marginal costs. Consequently, with higher output, to meet an equivalent emissions target, carbon prices must rise to

\footnotetext{
${ }^{16}$ See also Ben-David et al. (2000).

${ }^{17}$ An extreme but not uncommon type of output-based updating allocation mechanism is one in which a sources loses its allocation if it closes down or receives a free allocation if it enters.
} 
bring about additional reductions in emissions intensity and shift abatement to other covered sectors (Fischer and Fox 2007).

The use of this allocation mechanism may be motivated by a desire to protect certain industries from adverse competitiveness effects (Houser et al. 2008), or by a desire to limit price impacts on consumers. For example, HR 2454 - the so-called Waxman-Markey legislation employs this device for firms in energy-intensive trade-exposed sectors to limit the cost disadvantage that would otherwise shift competitiveness, economic activity, and emissions to countries without comparable regulation.

Unlike attempts to use ordinary free allocations to compensate the shareholders of firms in regulated sectors (which have no effects on behavior and no impacts on competitiveness), outputbased updating allocations compensate firms in a way that lowers their marginal production cost. The allocations in HR 2454 to local distribution companies, which are regulated entities with the mandate to pass on the cost savings to consumers, have effects similar to output-based allocations.

Because product prices are kept lower than would otherwise occur, output-based allocations discourage reliance on conservation and substitution to less emitting alternative products as a means for emissions reductions. Instead, to meet the cap, there is greater reliance on technological solutions and conservation in other sectors that are better able to pass on the costs (Fischer and Fox 2007). This means higher compliance costs. ${ }^{18}$ In the absence of pre-existing distortions, or if the allocations are poorly designed and inappropriately targeted, output-based allocations can reduce efficiency. ${ }^{19}$

\subsection{Non-Cost-Minimizing Behavior}

If some market participants are not cost-minimizing (not equating their marginal abatement costs with the prevailing allowance price), then the final allocation of allowances will likely be a function of the initial allocation. There are a variety of potential sources of such non-costminimizing behavior.

An interesting case is that of public entities as market participants. The international emissions quota regime established under Article 17 of the Kyoto Protocol allows trades in national targets ("assigned amount units" or AAUs) among nations. But there is no reason to assume that nations are simple cost-minimizers, or even if they sought to be that they would have the necessary information regarding their national abatement costs to carry out cost-effective international exchanges (Hahn and Stavins 1999). One might expect the pursuit of other national goals -

\footnotetext{
${ }^{18}$ Evaluating the cost-effectiveness of output-based allocations requires an assessment of other distortions that we have not emphasized here, namely tax interactions and the potential for emissions leakage (Fischer and Fox 2009, Bernard et al. 2007).

${ }^{19}$ An alternative policy for addressing emissions leakage is border adjustment. In theory, border adjustment is generally superior to output-based allocation, since border adjustment enables the preservation of the conservation signal to consumers by ensuring that comparable carbon costs are imposed on all products. However, many economists would nevertheless prefer the option of output-based allocation, because border adjustments may be more likely to invite retaliation, leading to reduced trade and consequent welfare losses. But, in principal, production subsidies can invite retaliation as well, so it is not clear which approach is better in practice.
} 
including, most obviously, the promotion of domestic industry or the reduction of (correlated) pollution in the nation - to prevent a public entity from pursuing a simple cost-minimizing strategy.

Behavioral economics provides several potential explanations for other sorts of non-costminimizing behavior. The endowment effect describes situations in which firms or individuals "overvalue" items already in their possession (Thaler 1980; Kahneman et al. 1990). If the firms granted emissions allowances tend to value them more highly than other firms simply because they happen to hold them, then fewer transactions will occur than would otherwise be predicted by market forces. If firms initially endowed with permits tend not to sell them, independence will not hold. While one could question whether a firm, as opposed to an individual consumer, might be subject to this cognitive bias, Murphy and Stranlund (2005) have suggested that the endowment effect may explain the low trading volumes in some cap-and-trade systems.

Status quo bias, a variant of the endowment effect, would lead to similar results. Like the endowment effect, status quo bias is a manifestation of loss aversion - where actors consider the disutility of parting with an item as being greater than the utility associated with obtaining it (Kahneman et al. 1991). A firm operating with such status quo bias might be expected to hold on to its initial allotment of permits simply because it has a preference for the status quo, whatever its mix of permits and abatement costs (Samuelson and Zeckhauser 1988).

Other sources of non-cost-minimizing behavior can also affect the performance of cap-andtrade markets. Even if managers wished to maximize profits, there may be such a high degree of organizational complexity in a firm that they cannot effectively do so (Tschirhart 1984). Related to this, principal-agent problems may cause firms not to minimize costs. The existence of "managerial slack" - in which a major consideration of firm decision-makers is "ease of management" - will preclude firms from attaining the cost-effective allocation of permits. A firm may continue to hold permits even if it would be more efficient to sell the permits and invest in abatement technology simply because it is administratively easier (Oates and Stassmann 1984).

A firm pursuing a goal of staff-maximization might fail to equate permit prices with marginal abatement costs: in this case, managers will favor either dealing in the permit market or investing in abatement, depending on which solution requires more workers. Unless these two solutions are equally labor-intensive, and firms have residual incentives to maximize profits, the efficient distribution of permits among firms will not be achieved (Tschirhart 1984).

In some scenarios, firms that are not generally cost-minimizing might nevertheless minimize costs with respect to emissions abatement. Oates and Strassmann (1984) have argued that this may be the case with the sort of managerial model of firms set forth by Williamson (1963). In this model, managerial utility includes a preference for expenditures on staff, salary and benefits for management, and "discretionary profits" - the excess of actual profits over the minimum profits required. If abatement contributes nothing positive or negative to staff expenditures or managerial salary, then firm managers will seek to maximize discretionary profits by minimizing expenditures on abatement - and will therefore act to equalize permit price with marginal abatement costs. The independent, cost-effective allocation of permits will result.

Another reason for a firm's departure from cost-minimizing behavior is associated with regulatory compliance. Proponents of "responsive regulation" have argued that firms often do not 
make decisions on whether or not to comply with a regulatory scheme based on simple benefit-cost calculations, but rather are motivated -- at least partly -- by factors such as the shame associated with violating a regulation perceived to be morally valid (Parker 2006; Braithwaite 2002). Firms may comply with regulations out of a sense of civic duty and because of the pressure imposed by other actors not to deviate from established norms (May 2005). Thus, if the initial allocation of permits affects firms' perceptions of the moral validity of a cap and trade scheme, it may influence their decisions whether or not to play by the rules, and thereby affect the ultimate allocation of permits. A particularly inequitable distribution, for example, could lead firms that initially received fewer permits to be less likely to participate in the permit market, and perhaps more likely to exceed the emissions limitations imposed upon them by the regulator.

Finally, firms may be reluctant to engage in trading in the beginning stages of a market. For example, if a firm manager is risk averse, he may try to meet the emission target that is implicitly defined by the firm's initial allocation. So, he would minimize costs across different plants that are part of the company, subject to the constraint that emissions do not exceed the initial allocation. Ellerman (2000) calls this autarkic compliance. In the early years of the $\mathrm{SO}_{2}$ trading system, some utilities appear to have pursued this strategy.

\subsection{Differential Regulatory Treatment}

If firms receive different regulatory treatment, then initial allocations of allowances can affect equilibrium allocations, performance, and cost. State-level regulation of electricity producers, such as rate-of-return regulation, can discourage or even prevent firms from cost-minimizing with respect to emissions (Hahn and Noll 1983; Tschirhart 1984; Oates and Strassman 1984). In addition, regulators may discourage trading, due to concerns about local pollution (Fullerton et al. 1997). Finally, if a cap-and-trade system is interstate, then jurisdictions may be regulated differently. In all of these cases, the equilibrium allocation will not be independent of the initial allocation, and the outcome will not be cost-effective. ${ }^{20}$

Under typical rate-of-return regulation, utilities are permitted to extract only those revenues that are linked with certain costs determined by the regulator to be recoverable. Under the original cost method of rate-making, a utility is allowed to retain as revenue its annual depreciation plus a certain proportion of its original expenditure on capital facilities. If permits are given out, rather than sold, then the utility will not have spent anything to acquire its permit holdings and the value of these permits will not be incorporated in its rate base. This problem is compounded by the common requirement that any gains from the sale of assets must be factored into utility prices - thus these utilities will effectively be taxed $100 \%$ on any revenue from the sale of permits. Utilities will therefore have incentives to spend money on other abatement mechanisms, a variation on Averch and Johnson's (1962) observation that regulated utilities will tend to overinvest in capital goods.

In states that calculate rates based on the replacement cost method - adjusting the original cost of capital goods based on inflation and technological change - the above problems would not arise, as the market price of permits would be used to adjust the value of the utility's rate base, and

\footnotetext{
${ }^{20}$ Obviously, a cap-and-trade system that restricts certain trades will violate the independence property if the restrictions are binding.
} 
thus the utility might be expected to minimize abatement costs (Hahn and Noll 1983). If the permit market spans several states, and some participants are subject to original cost method regulation, then the cost-effective allocation will not be attained, as the lack of incentives to cost-minimize will prevent the market from clearing efficiently. Further distortions are introduced if expenditures on abatement technologies are permitted to earn higher rates of return than amounts expended on emissions permits, or if some abatement assets can be depreciated at a faster rate, or treated as operating costs (Bohi and Burtraw 1992).

Problems can arise with respect to efficiency even if regulatory treatment is the same across utilities. Suppose there is free allocation for utilities in all states. This could lead to lower product prices (e.g., for electricity) due to regulation, as noted above. These product prices will not generally reflect incremental costs (due to the nature of regulation), and will thus give rise to allocative inefficiencies (Spulber 1985). In particular, the equilibrium would be affected by how many allowances the utility sector is given directly. These problems can be addressed by allowing utilities to purchase allowances from local distribution companies, as suggested in the the Waxman-Markey legislation.

Finally, regulators might conceivably take proactive steps that prevent the cost-effective allocation from being reached. If concerned about local pollution, a state regulator might implement rules that discourage the purchase of emissions permits, thus limiting the extent to which permits granted to utilities in other regions may cross political boundaries (Fullerton et al. 1997). ${ }^{21}$ In this scenario, the express purpose of regulation would be to ensure that independence does not hold, and that firms are not allowed to increase their emissions to the amount that would be cost-effective for them and for the system as a whole.

\section{Empirical Assessment of Effects of Allowance Allocation on Performance of Cap-and-Trade Systems}

In this part of the paper, we assess the independence property in existing and planned capand-trade systems. Our analysis proceeds in two ways: descriptively, by assessing the presence of the various conditions that could lead to a violation of the independence property; and statistically, by reviewing studies that test whether the final allocation of permits is affected by the initial allocation.

Market imperfections are present in most real-world markets. For example, in most markets, there are transactions costs in bringing buyers and sellers together. The question for our purposes is whether these market imperfections turn out to be important in terms of leading to significant violations of the independence property. We examine eight past and present cap-and-trade systems and four proposed systems.

\subsection{Experience with Past and Present Systems}

We investigate a number of existing cap-and-trade systems: lead trading; CFCs under the Montreal Protocol; the $\mathrm{SO}_{2}$ allowance trading program; the Regional Clean Air Incentives Market

\footnotetext{
${ }^{21}$ Of course, there may be efficiency rationales for limiting trading when there is non-uniform mixing of pollutants or hotspots.
} 
(RECLAIM) in Southern California; the eastern ozone transport $\mathrm{NO}_{\mathrm{X}}$ market; the European Union Emission Trading Scheme (EU ETS); Article 17 of the Kyoto Protocol; and the Regional Greenhouse Gas Initiative.

\subsubsection{Lead Trading}

In 1973, the U.S. Environmental Protection Agency (EPA) began to impose regulations requiring refineries to reduce the content of lead in gasoline. In 1982, in conjunction with new, lower limits on lead content, EPA authorized inter-refinery trading of lead credits. If refiners produced gasoline with a lower lead content than was required, they earned lead credits, which could then be traded to other refineries. A major purpose of the program was to lessen the financial burden on smaller refineries, which were believed to have significantly higher compliance costs. In 1985, EPA initiated a program allowing refineries to bank lead credits. In 1987, the program was terminated when the lead phasedown was completed (Stavins 2003).

The leaded gasoline phasedown is generally considered to have been a success (Kerr and Mare 1998). Part of this success has been attributed to the lack of regulatory restrictions on trading lead credits, the relatively low costs of trading, and the prior existence of markets among refineries for products such as gasoline additives (U.S Environmental Protection Agency, Office of Policy Analysis, 1985; Hahn and Hester 1989; Kerr and Newell 2001).

There is some evidence that transaction costs may have reduced the cost-effectiveness of the program. In a sample of 87 refineries from 1983 through 1984, 20\% of the refineries had not participated in the market at all, suggesting that the market was probably not achieving the competitive equilibrium in the absence of transaction costs (Kerr and Mare 1998). Empirical analysis suggested that larger firms, and firms with a larger number of refineries, faced lower transaction costs. ${ }^{22}$

Regulatory uncertainty may have added to transaction costs. Refineries calculated whether they would have excess lead credits to transfer, and traded these credits before they were verified by EPA. In some cases, permits that were traded were later revealed to be invalid. Refineries therefore incurred additional costs assessing the reputation of trading partners and investigating the validity of permits being sold. These costs led to a decrease in the cost-effectiveness of the program on the order of 10 to 20 percent (Kerr and Mare 1998).

\subsubsection{CFC Trading Under the Montreal Protocol}

The Montreal Protocol - established in 1987 to limit emissions that damaged the earth's stratospheric ozone layer - required reductions in the use of chlorofluorocarbons ("CFCs") and halons. The Protocol called for a 50\% reduction in the production of particular CFCs from 1986 levels by 1998, and froze halon production and consumption at 1986 levels beginning in 1992. Each country that signed the agreement was allowed to choose its own mechanism for limiting emissions. The United States implemented a cap-and-trade system in 1988 to help it comply with the Protocol. The system placed limitations on both the production and use of CFCs by issuing allowances that

\footnotetext{
${ }^{22}$ Given that property rights were allocated based on production, this system had features of an output-based allocation. See above.
} 
limited these activities. Because different types of CFCs have different effects on ozone depletion, each CFC was assigned a different weight on the basis of its depletion potential.

The production of CFCs was highly concentrated, with two producers - Du Pont and Allied Signal -accounting for $75 \%$ of domestic production, and Du Pont alone holding a 49\% market share. Because the Protocol did not allow for allowance trading across countries, these producers were shielded from potential international competition. There was therefore a real possibility that these firms might use their market power to manipulate the CFC allowance price. The EPA considered trying to dilute this potential price-setting ability by distributing production permits to importers as well as producers, but it ultimately decided to limit the allowance market to producers to minimize transaction and administrative costs (Hahn and McGartland 1989).

While the cap and trade program was a success - in that the limits imposed by the Protocol were reached - the overall efficiency of the market is difficult to determine because no studies have been conducted to estimate cost savings (Stavins 2007). In summary, it appears that market power could have led to a violation of the independence property in the case of CFC trading, but there is no empirical evidence.

\subsection{3 $\mathrm{SO}_{2}$ Allowance Trading Under the Clean Air Act Amendments of 1990}

The most important application in the United States of a market-based instrument for environmental protection is arguably the cap-and-trade system for regulating emissions of sulfur dioxide $\left(\mathrm{SO}_{2}\right)$. Sulfur dioxide is the primary precursor of acid rain, and a local pollutant with significant negative human health effects. This system, which was established under Title IV of the U.S. Clean Air Act Amendments of 1990, was intended to reduce $\mathrm{SO}_{2}$ emissions by 10 million tons (approximately 50\%) below 1980 levels by the year 2000. The first phase of sulfur dioxide emissions reductions was started in 1995, with a second phase of reduction initiated in the year 2000 (Stavins 2003).

The program resulted in substantial cost savings relative to command-and-control regulation, with estimated annual cost savings ranging between $\$ 250$ million and $\$ 1.6$ billion, compared with an estimated $\$ 3$ billion baseline (Carlson et. al 2000). ${ }^{23}$ Of course, substantial cost savings do not imply that costs were necessarily minimized. It has been estimated that actual abatement costs exceeded the least-cost solution by $\$ 280$ million in 1995 and by $\$ 339$ million in 1996 (Carlson et. al 2000). ${ }^{24}$ More than half of sources appeared not to have switched to using low-sulfur coal when it was economical. $^{25}$

\footnotetext{
${ }^{23}$ Ellerman et al. (2000) report similar estimates, finding that costs of compliance were $55 \%$ of those that would be incurred under a command-and-control regime.

${ }^{24}$ Ellerman et al. (2000), in contrast, estimate that the cost of the program exceeded the least-cost solution by significantly less in Phase I (between 3\% and 15\% in their estimate).

${ }^{25}$ Similar findings were reported by Swinton (2002), who examined the actions of seven coal-powered power plants in Florida from 1990 to 1998.
} 
One possible explanation for deviations from the cost-minimizing outcome is the existence of transaction costs, particularly at the beginning of the program. ${ }^{26}$ Firms initially confronted a very thin allowance market (Burtraw 1996). Transactions increased significantly over time, with the number of allowances traded doubling nearly every year during the first three years, an increase which is consistent with transaction costs decreasing as firms gained experience trading (Burtraw et al. 2005). By 1996, transaction costs were relatively low, with the average commission charged per trade less than $2 \%$ (Joskow et al. 1998). ${ }^{27}$

Regulation may have brought about another distortion in the allowance market. Concerns were expressed that state regulatory authorities would limit trading to protect their domestic coal industries, and some research indicates that some state cost-recovery rules were inefficient. One study examined the eleven states that would receive the most allowances, and found that in six of these states there was a regulatory bias for utilities to pursue other means of compliance (for example, installing scrubbers or switching fuel types) in lieu of purchasing allowances (Bohi 1994). But other analysis concluded that PUC regulations did not substantially affected the allowance market (Bailey 1998). Subsequent research found a statistically significant relationship between a utility being subject to PUC regulations and its likelihood of choosing certain abatement methods in Phase I (Amiru 2002). Regulated firms were more likely to switch to using low-sulfur coal, which was relatively costly in comparison with purchasing allowances.

Utility regulations may have contributed to uncertainty. Although the Federal Energy Regulatory Commission (FERC) established guidelines for accounting rules in 1993, FERC and the various state PUCs did not immediately set cost recovery rules; and many utilities were unsure of how allowance transactions would be treated (Burtraw 1996). Many utilities apparently felt comfortable trading allowances even in the absence of any sort of ruling (Bailey 1998). And the lack of formal guidance at the outset of the program does not appear to have impeded the development of the allowance market (Ellerman et al. 2000).

The presence of market power does not appear to have been a problem. From 1995 through 2003, the path of emissions was consistent with that expected from perfect competition (Ellerman and Montero 2007). Also, the compliance decisions of the four largest firms in the market from 1995 through 1999, which accounted for $43 \%$ of the total allowances granted, exhibit no evidence of market manipulation (Liski and Montero 2009).

In summary, it appears that, at least in the early years of the $\mathrm{SO}_{2}$ cap-and-trade program, a perfectly cost-effective allocation of permits was not achieved, due in part to high transaction costs and utility regulations. But later, as trading became more frequent, transaction costs fell, and utility regulations were clarified. The subsequent market was likely consistent with the independence property.

\footnotetext{
${ }^{26}$ Another possible explanation of the deviation observed by Carlson et al. (2000) may be that it is due to the use of an ex-ante, not ex-post analysis (Ellerman et al. 2000).

${ }^{27}$ Transaction costs may have been relatively low because the auctions the EPA conducted in order to distribute allowances helped facilitate price discovery (Schmalensee et al. 1998).
} 


\subsubsection{RECLAIM}

The South Coast Air Quality Management District (SCAQMD), which is responsible for controlling emissions in a four-county area of southern California, launched a cap-and-trade program in 1994 to reduce nitrogen oxide $\left(\mathrm{NO}_{\mathrm{x}}\right)$ and $\mathrm{SO}_{2}$ emissions in the Los Angeles area. This Regional Clean Air Incentives Market (RECLAIM) set an aggregate cap on $\mathrm{NO}_{\mathrm{x}}$ and $\mathrm{SO}_{2}$ emissions for all power plants, cement factories, refineries, and other industrial sources with emissions greater than four tons per year, employing a trading program which incorporates zonal restrictions, whereby trades are not permitted from downwind to upwind sources. The program also incorporates temporal restrictions, with the banking of permits limited (Stavins 2008).

In an analysis directly examining whether the RECLAIM market exhibited the independence property, the evidence indicated that it did (Fowlie and Perloff 2008). Regulators had randomly assigned firms in RECLAIM to one of two permit allocation cycles. Permit allocations were generally decreasing over time, and depending on which cycle a firm was randomly assigned to, the decline in a firm's allocation might occur either in January or July. Employing instrumental variable procedures - and using random assignment into one of the two cycles as the instrument there was no evidence of a statistically significant relationship between the initial and final permit allocation (Fowlie and Perloff 2008).

At the same time, evidence suggests that the RECLAIM market has not achieved all of its cost-saving potential. ${ }^{28}$ Transaction costs were present, due in part to the heterogeneous nature of firms participating in the market, with the result that the average facility had only a $20 \%$ probability of engaging in trade. The reduction in trading due to transaction costs has been estimated to be 32\% (Gangadharan 2000).

These transaction costs likely decreased in subsequent years, as brokers and other intermediaries entered the market (Ellerman et al. 2003). Whereas only 28\% of permit transactions in 1994 used brokers, by 2001 brokers were involved in 75\% of trades (Fowlie and Perloff 2008). Transaction costs appear to be modest, as evidenced by the high volume of trading in the market, ${ }^{29}$ and by SCAQMD's decision in 2002 to reject as unnecessary a proposal that would have established a centralized market for all RECLAIM permit transactions.

Uncertainty may also have created distortions in the permit market. One source of uncertainty resulted from the actions of a major private broker, which has been sued more than once for failing to deliver purchased emissions permits (Fowlie and Perloff 2008). The seventeen amendments to the program rules between 1994 and 2006 likely contributed to firm uncertainty regarding the permit market (Fowlie and Perloff 2008). Furthermore, there has been price volatility, with spikes in the price of $\mathrm{NO}_{\mathrm{X}}$ permits in 2000 due to a spike in California energy prices, which ultimately required SCAQMD to remove electricity generators from the market. This price spike

\footnotetext{
${ }^{28}$ One prospective analysis predicted cost savings of approximately $40 \%$ from the emissions trading program as compared with then-existing command and control regulation (Johnson and Pekelney 1996).

${ }^{29} \mathrm{By}$ the end of 1997, permits corresponding to a total of 244,000 tons of emissions had been transferred (Nash and Revesz 2001), while as of the end of 2001 the corresponding figure was over 400,000 (Ellerman et al. 2003).
} 
does not reflect a failing of the RECLAIM market design itself, but rather flaws in California's deregulation of its electricity market (Harrison 2003).

The RECLAIM market appears to have functioned reasonably well. A direct statistical test of the independence property cannot reject the claim that the final allocation is independent of the initial allocation, but initial high transactions costs could have led to a violation of the independence property in the early years of the program.

\subsubsection{Eastern Ozone Transport $\mathrm{NO}_{\mathrm{X}}$ Market}

Under U.S. EPA guidance, twelve northeastern states and the District of Columbia implemented a regional $\mathrm{NO}_{\mathrm{X}}$ cap-and-trade system in 1999 to reduce compliance costs associated with the Ozone Transport Commission regulations of the 1990 Amendments to the Clean Air Act. ${ }^{30}$ Under the program, EPA distributes $\mathrm{NO}_{\mathrm{X}}$ allowances to each state, and states allocate allowances to sources in their jurisdictions. Sources may buy, sell, and bank allowances, although a system of progressive flow controls limits the total number of banked allowances that can be used during the ozone season (Stavins 2003).

This program appears to have been successful. $\mathrm{NO}_{\mathrm{X}}$ emissions fell from 1.9 million tons in 1990 to 500 thousand tons in 2006 (Stavins 2007). An ex ante examination estimated cost savings of between $40 \%$ and $47 \%$ for the period $1999-2003$ as compared with command-and-control regulation (Farrell, Carter, and Raufer 1999). Another assessment cited the low price of allowances during the first year of emissions trading as evidence that the system was efficient (Farrell 2001; Farrell and Lave 2004). ${ }^{31}$

There is, however, some evidence that distortions may have affected the workings of the allowance market. Interviews with participants in the Ozone Transport Region revealed that firms had generally been conservative in their trading of allowances (Farrell 2003). First, they believed that there was a great deal of uncertainty in the market, and were unsure of their ability to purchase and sell allowances. Second, due to market thinness, some firms thought they had some pricesetting power, and thus abstained from purchasing (selling) allowances if doing so would raise (lower) the price (Farrell 2003). In summary, despite some concerns that arise from survey results, this market has appeared to work reasonably well, and has reduced the costs of limiting emissions.

\subsubsection{European Union Emission Trading System}

In order to meet its commitments under the Kyoto Protocol, the European Union adopted in 2003 the European Union Emission Trading Scheme (EU ETS), a cap-and-trade system for $\mathrm{CO}_{2}$ emissions reduction. This downstream system covers about half of EU emissions from some 11,500 sources, including large sources such as oil refineries, combustion installations over $20 \mathrm{MW}$, coke ovens, cement factories, ferrous metal production, glass and ceramics production, and pulp and paper production. The program does not cover sources in the transportation, commercial or

\footnotetext{
${ }^{30}$ Only nine of the twelve states actively participated in the program (Farrell 2001).

${ }^{31}$ Including reductions achieved under the $\mathrm{NO}_{\mathrm{X}}$ SIP Call, $\mathrm{NO}_{\mathrm{X}}$ emissions fell from 1.86 million tons in 1990 to .49 million tons in 2006 (Stavins 2008).
} 
residential sectors. The EU ETS was designed to be implemented in phases: a pilot or learning phase from 2005 to 2007, a Kyoto commitment period phase from 2008 to 2012, and a series of subsequent phases (Stavins 2008).

Direct statistical evidence exists in support of the independence property (Reguant and Ellerman 2008). In Spain, European Union allowances (EUAs) were allocated based on a function that rewards certain cleaner sources. Because of this allocation method, the endogeneity problems normally present in testing for independence could be avoided. No evidence was found that the initial allocation of EUAs had an effect on firms’ production decisions.

Other evidence suggests that there have been relatively few distortions in the market for EUAs. Given the large number of sources covered by the program, few if any firms are capable of exercising market power. The largest player in the EUA market (in the trial phase) was allocated less than $6 \%$ of allowances. Even if the electricity generating sector - which contained seven of the top ten firms in terms of initial EUA holdings - were to be considered as a whole, there is no empirical evidence of market power (Convery and Redmond 2007).

Transaction costs also have been low. Although the ETS involves several nations, trading between firms in different countries has been frequent, due in large part to the presence of intermediaries in the EUA market (Ellerman 2008). Brokers entered the market even before the ETS went online, with futures trading beginning in 2004. And several companies, such as Point Carbon, facilitated transactions by tracking and reporting developments in the EUA market, providing information on prices for both buyers and sellers (Convery and Redmond 2007).

Distortions were introduced by provisions that grant allowances freely to new entrants to the market, and that require that unused allowances be forfeited by any facility that shuts down. Like output-based updating allocations, these provisions subsidize production, and cause the independence property to be violated (Ellerman and Buchner 2007).

\subsubsection{Kyoto Protocol (Article 17)}

In 1990, negotiations commenced that led to agreement in 1992 on the United Nations Framework Convention on Climate Change (UNFCCC), which entered into force in 1994 with 190 countries as parties, and established a long-term goal of stabilizing greenhouse gas concentrations in the atmosphere at a level that would prevent dangerous anthropogenic interference with the climate system. In Kyoto, Japan, in December 1997, the parties to the UNFCCC agreed on the terms of what came to be known as the Kyoto Protocol. The Protocol includes a provision for cost-effective implementation through a set of tradable permit mechanisms, two of which are credit programs (Joint Implementation and the Clean Development Mechanism) and one of which is a cap-and-trade system (the international trading provision in Article 17). These are provided as options that countries can employ.

The agreement was intended to result in industrialized countries' emissions declining in aggregate by 5.2\% below 1990 levels by the year 2012. Despite the failure of the United States and 
Australia to ratify the Protocol, ${ }^{32}$ the agreement became effective in 2005, having met the requirement that 55 Annex I (largely, industrialized) countries, jointly accounting for 55\% of 1990 Annex I emissions, had ratified the agreement (Stavins 2008).

Early on, the emissions trading provision of Article 17 was hailed by many as the most effective of the three compliance mechanisms (Weyant and Hill 1999). But others noted reasons to be skeptical (Hahn and Stavins 1999). First, one might not expect the market created by Article 17 to exhibit independence and achieve cost-effectiveness, because the relevant market actors are nations, not private firms. Nations, unlike firms, are unlikely to have the incentive or the capability to act in a cost-minimizing way. Hence, nations are unlikely to equate their marginal abatement costs with permit prices (Hahn and Stavins 1999). Moreover, the status of the participants in the markets as sovereign nations also provides a strong opportunity for non-compliance, as participation in the market is ultimately voluntary.

Another problem is that some participants in the Article 17 market may be large enough to manipulate permit prices to their advantage (Bernard et al. 2003). Such countries may be able to raise prices by subsidizing certain abatement technologies, or lower prices by imposing a tariff on permit exports. Even if a nation were to distribute its allowances to firms within its jurisdiction, it may be able to implement policies that encourage these firms to coordinate their actions (Liski and Montero 2009).

Another concern raised with respect to Article 17 trading has been transactions costs. The Protocol involves many countries, with distinct characteristics and experiences with emissions abatement. One might therefore expect permit trade between these countries to feature significant search and information costs (Pan and Regemortor 2004). The EU ETS may be considered an efficient sub-market of the overarching Article 17 permit market that helps lower transaction costs, although the existence and conduct of the EU ETS does not depend upon Article 17 of the Kyoto Protocol.

While markets established in response to the Kyoto Protocol targets, such as the EU ETS, may be relatively cost-effective, it is unlikely that final permit allocations are independent of initial allocations in the international permit market created by Article 17 itself. Problems with non-costminimizing behavior, strategic price manipulation, and transaction costs could be significant.

\subsubsection{Regional Greenhouse Gas Initiative}

The Regional Greenhouse Gas Initiative (RGGI) is a downstream cap-and-trade program intended to limit $\mathrm{CO}_{2}$ emissions from power-sector sources in ten northeastern states (Connecticut, Delaware, Maine, Maryland, Massachusetts, New Hampshire, New Jersey, New York, Rhode Island, and Vermont). The program took effect in 2009, and sets a goal of limiting emissions from regulated sources to 2008 levels in the period from 2009 to 2014. Beginning in 2015, the emissions cap decreases by 2.5\% per year until it reaches an ultimate level 10\% below 2008 emissions in 2019 .

The program has performed reasonably, although because of the economic recession and other factors, the cap has hardly been binding. Also, because of the limited geographic coverage of

\footnotetext{
${ }^{32}$ Australia subsequently ratified the Kyoto Protocol, late in 2007.
} 
the system, it is anticipated that leakage could reach 50\% (Kolodziej and Wing 2009). Beyond these fundamental issues, it is anticipated that transaction costs are relatively low, because the sources involved are homogenous (Stavins 2008). Since allowances were first issued, transactions have been equivalent to more than $25 \%$ of the annual emissions cap (RGGI 2010). Overall, it is too soon to judge whether the independence property holds in this system. ${ }^{33}$

\subsection{Anticipated Effects of Proposed Systems and Changes in Existing Systems}

We examine four cap-and-trade systems that may be modified or implemented in the future: the EU ETS, as amended for 2012; the New Zealand Emissions Trading Scheme; the Australian capand-trade system; and the American Clean Energy and Security Act (HR 2454).

\subsubsection{Post-2012 Changes to the EU ETS}

In December 2008, the European Parliament approved amendments to the EU ETS, revising the market framework for 2012 and subsequent years. One major change is an increased degree of centralization, with a single European Community registry. Member states will have less discretion to determine how many allowances will be distributed within their borders, which will decrease the uncertainty regarding the overall level of the cap (Commission of the European Communities 2008). A requirement that member states distribute approximately two-thirds of their allowances through auction may provide a useful price signal.

The program will be expanded to new industrial sectors, amounting to an increase of $7 \%$ coverage (Commission of the European Communities 2008). This could lower transactions costs through greater market liquidity. On balance, these changes may reduce transaction costs and make the EU ETS market more efficient.

\subsubsection{New Zealand Emissions Trading Scheme}

With its Climate Change Response Act of 2002, New Zealand initiated its efforts to create a cap-and-trade system to reduce emissions of greenhouse gases. The system began functioning in 2008 for the forestry sector, with industrial sectors to be introduced on a rolling basis (transport, electricity and industrial sectors to be included in 2010, synthetic gases and waste sectors in 2011, and the agricultural sector by 2015). Along with $\mathrm{CO}_{2}$ emissions, the New Zealand system provides for trading in other GHGs, including methane and nitrous oxide.

New Zealand's planned system is the first to include agricultural emissions within a cap-andtrade scheme. However, compliance may be challenging in this sector, which is composed of many relatively small units (Kerr and Zhang 2009). These participants may experience high transaction costs in the permit market, at least at the outset, because the presence of many small, unsophisticated actors in a market in which they have very limited experience could raise the costs of allowance exchanges. Helping to mitigate such costs is the fact that the agricultural sector will not be incorporated until a later phase when the overall market has already developed. The provision of education and information services by the government may also help reduce these costs over time

\footnotetext{
${ }^{33}$ An increasing share of RGGI allowances are auctioned, a distinction which is beyond the scope of our analysis.
} 
(Kerr and Zhang 2009). In addition, experience with the system may also reduce transaction costs, as potential buyers and sellers become more comfortable with participating in the market.

Significantly, the system employs an output-based updating allocation mechanism, which as highlighted above - violates the independence property. A key remaining issue for whether the independence property will apply in this market is transaction costs associated with trading. This, in turn, will be affected by whether there is international trading.

\subsubsection{Australia Carbon Pollution Reduction Scheme}

Australia was originally scheduled to commence its Carbon Pollution Reduction Scheme (CPRS) in 2010. The planned cap-and-trade system set limits on the emissions of greenhouse gases, yielding reductions of as much as $25 \%$ of 2000 levels by 2020. After criticism was lodged against the proposed scheme - regarding its emissions target and the estimated costs of compliance - an amended version was proposed in 2009. Among other changes, the proposed start date was deferred to 2011. In December of 2009, however, the Senate voted against the CPRS legislation, delaying the implementation of the carbon cap-and-trade system. ${ }^{34}$

The CRPS, as proposed, would include a price cap for carbon allowances that would limit uncertainty in the cost of compliance (Jotzo and Betz 2008). In particular, during 2011-12, an unlimited number of allowances would have been available for purchase from the Australian government at a price of $\$ 10$ per ton. From 2012-13 to 2015-16, a price cap of $\$ 40$ per ton would be put in place, increasing by 5\% each year and indexed for inflation (Australian Government Department of Climate Change 2009). Banking was to be strictly limited to prevent firms from exploiting these provisions.

As with the New Zealand ETS, the CPRS could eventually be extended to cover the agricultural sector. The government had proposed to decide in 2013 whether agricultural emissions would be included in the scheme by 2015. While expanding the sectoral coverage of the scheme could in theory reduce compliance costs by providing more trade (and emission-reduction) opportunities (Ford et al. 2009), these smaller and more inexperienced actors may face relatively high transaction costs.

If and when some modified version of the CRPS is enacted and comes into force, it is likely to face issues similar to those New Zealand will confront with its ETS. As with that system, it is too early to say whether the Australian market will support the independence property.

\subsubsection{HR 2454: American Clean Energy and Security Act (Waxman-Markey)}

In the United States, the Waxman-Markey bill would establish an economy-wide cap-andtrade system to cover the emission of greenhouse gases. The short-term and long-term targets are to reduce U.S. emissions 17\% below 2005 levels by 2020, and 80\% below 2005 levels by 2050, respectively. Approximately $85 \%$ of all U.S. emissions would be covered by the system. The House

\footnotetext{
${ }^{34}$ See: http://www.climatechange.gov.au/en/government.aspx.
} 
of Representatives passed the legislation in June of 2009, but with a lack of final action in the Senate, it is not clear what form the final legislation and system will take.

One significant component of the Waxman-Markey system is the inclusion of output-based updating allocations. Such an allocation mechanism functions as a subsidy to production, and firms will tend to produce more of their products than otherwise, driving up the abatement costs necessary to achieve any given level of emission reductions.

Output-based updating allocation is employed in the legislation for the purpose of protecting the international competitiveness and reducing leakage from sectors that are particularly energyintensive and trade-sensitive. Also, the allocation mechanism is used for merchant coal generators, thereby discouraging reductions in coal-fired electricity generation, another significant and costly distortion. Overall, the use of output-based allocations suggests that the Waxman-Markey bill, if implemented, would lead to a relatively minor violation of the independence property.

\section{Conclusions}

What has come to be known as the "Coase Theorem" - the assertion that under certain conditions, bilateral negotiation between the generator and recipient of an externality will lead to the same efficient outcome regardless of the initial assignment of property rights - has had important impacts not only on environmental (and other areas of) economics, but also on the development of public policy in the environmental domain. Its close relative, the independence property, has been particularly important in gaining support for the use of cap-and-trade systems to address environmental issues.

This property is of great relevance to the practical development of policy, because it allows equity and efficiency concerns to be separated. In particular, a government can set an overall cap of pollutant emissions (that is, a pollution-reduction goal), and leave it up to a legislature to construct a constituency in support of the program by allocating shares of the allowances to various interests, such as sectors and geographic regions, without affecting either the environmental performance of the system or its aggregate social costs.

Because of the importance of this property, we have examined the conditions under which it is more or less likely to hold - both in theory and in practice. We find that in theory, a number of factors can lead to the independence property being violated. These are: particular types of transaction costs in cap-and-trade markets; significant market power in the allowance market; uncertainty regarding the future price of allowances; conditional allowance allocations, such as output-based updating allocation mechanisms; non-cost-minimizing behavior by firms; and specific kinds of regulatory treatment of participants in a cap-and-trade market.

Of course, the fact that these factors can lead to violation of the independence property does not mean that in practice they do so in quantitatively significant ways. Hence, we have examined both indirect (circumstantial) evidence regarding the presence and importance of these various factors in past and present cap-and-trade systems, as well as direct (statistical) evidence of the violation of the independence property in these systems. In a review of both sources of evidence in 
eight past and present cap-and-trade systems, we find that support for the independence property is strong in half of the systems, and moderate in two others (Table 1).

The fact that the independence property appears to be broadly validated provides support for the efficacy of past political judgments regarding constituency-building through legislatures' allowance allocations in cap-and-trade systems. Repeatedly, governments have set the overall emissions cap and then left it up to the political process to allocate the available number of allowances among sources to build support for an initiative without reducing the system's environmental performance or driving up its cost. This success with environmental cap-and-trade systems should be contrasted with many other public policy proposals for which the normal course of events is that the political bargaining that is necessary to develop support reduces the effectiveness of the policy or drives up its overall costs. 
Table 1:

Summary of Empirical Findings Regarding Independence Property

\begin{tabular}{|l|l|l|}
\hline \multicolumn{1}{|c|}{ Cap-and-Trade System } & \multicolumn{1}{c|}{$\begin{array}{c}\text { Indirect Evidence } \\
\text { of Possible } \\
\text { Permit Market Distortions }\end{array}$} & $\begin{array}{c}\text { Support } \\
\text { for Independence Property }\end{array}$ \\
\hline Lead Trading & Transaction Costs & Medium \\
\hline CFC Trading under Montreal Protocol & Market Power & Medium \\
\hline $\mathrm{SO}_{2}$ Allowance Trading & $\begin{array}{l}\text { Transaction Costs, } \\
\text { Differential Regulatory } \\
\text { Treatment, Uncertainty }\end{array}$ & $\begin{array}{l}\text { Low at the outset } \\
\text { Subsequently high }\end{array}$ \\
\hline RECLAIM & $\begin{array}{l}\text { Transaction Costs, } \\
\text { Uncertainty }\end{array}$ & High* \\
\hline Eastern Ozone Transport $\mathrm{NO}_{\mathrm{X}}$ & $\begin{array}{l}\text { Market Power, Uncertainty, } \\
\text { Non-Cost-Minimizing } \\
\text { Behavior }\end{array}$ & High \\
\hline EU ETS & Uncertainty? & High* \\
\hline Kyoto Protocol Article 17 & $\begin{array}{l}\text { Transaction Costs, } \\
\text { Market Power, Non-Cost- } \\
\text { Minimizing Behavior }\end{array}$ & Low \\
\hline Regional Greenhouse Gas Initiative & Uncertainty? & Unknown \\
\hline
\end{tabular}

*Partly based on statistical tests. Only those applications of cap-and-trade considered in the text are included. 


\section{REFERENCES}

Alberola, E. and J. Chevallier. (2009). "European Carbon Prices and Banking Restrictions: Evidence from Phase I (2005-2007).” The Energy Journal 30:51-79.

Arimura, T.H. (2002). “An Empirical Study of the SO2 Allowance Market: Effects of PUC Regulations.” Journal of Environmental Economics and Management 44:271-289.

Australian Government Department of Climate Change. (2009). Summary: Key Changes to the Carbon Pollution Reduction Scheme Legislation.

Averch, H. and L. Johnson. (1962). "Behavior of the Firm Under Regulatory Constraint.” American Economic Review 52:1052-1069.

Bailey, E.M. (1998). “Allowance Trading Activity and State Regulatory Rulings: Evidence from the U.S. Acid Rain Program.” Center for Energy and Environmental Policy Research Working Paper No. 98005, MIT.

Baldursson, F.M. and N.H.M. von der Fehr. (2004). "Price Volatility and Risk Exposure in Market-Based Environmental Policy Instruments.” Journal of Environmental Economics and Management 48:682704.

Ben-David, S., D. Brookshire, S. Burness, M. McKee, and C. Schmidt. (2000). “Attitudes toward Risk and Compliance in Emission Permit Markets.” Land Economics 76:590-600.

Bernard A., S. Paltsev, J. Reilly, M. Vielle and L. Viguier. (2003). "Russia’s role in the Kyoto Protocol.” Report No. 98, Joint Program on the Science and Policy of Global Change, MIT, Cambridge, Massachusetts.

Bernard, A., C. Fischer, and A. Fox. (2007) "Is There a Rationale for Output-based Rebating of Environmental Levies?” Resource and Energy Economics 29 (2): 83-101.

Betz, R. and A. Gunnthorsdottir. (2009). "Modeling Emissions Markets Experimentally: The Impact of Price Uncertainty.” Unpublished Manuscript.

Bohi, D.R. (1994). "Utilities and State Regulators Are Failing to Take Advantage of Emission Allowance Trading.” Electricity Journal 7(March):20-27.

Bohi, D.R. and D. Burtraw. (1992). "Utility Investment Behavior and the Emission Trading Market.” Resources and Energy 14:129-153.

Buchanan, J. M. and G. Tullock. (1975). "Polluters' Profits and Political Response: Direct Control Versus Taxes.” American Economic Review 65:139-147.

Burtraw, D. (1996). "The SO2 Emissions Trading Program: Cost Savings Without Allowance Trades." Contemporary Economic Policy 14:79-94.

Burtraw, D., D.A. Evans, A. Krupnick, K. Palmer and R. Toth. (2005). "Economics of Pollution Trading for SO2 and NOx.” Annual Review of Environment and Resources 30:253-289. 
Braithwaite, J. (2002). Restorative Justice and Responsive Regulation. Oxford, United Kingdom: Oxford University Press.

Carlson, C., D. Burtraw, M. Cropper and K.L. Palmer. (2000). "Sulfur Dioxide Control by Electric Utilities: What Are the Gains from Trade?” Journal of Political Economy 108:1292-1326.

Cason T.N. and L. Gangadharan. (2003). "Transactions Costs in Tradable Permit Markets: An Experimental Study of Pollution Market Designs.” Journal of Regulatory Economics 23:145-165.

Chao, H. and R. Wilson. (1993). “Option Value of Emission Allowances.” Journal of Regulatory Economics 5:233-249.

Coase, R. (1960). “The Problem of Social Cost.” Journal of Law and Economics 3:1-44.

Commission of the European Communities. (2009). Official Journal of the European Union, "Directive 2009/29/EC of the European Parliament and of the Council of 23 April 2009 amending Directive 2003/87/EC so as to improve and extend the greenhouse gas emission allowance trading scheme of the Community.” May 6, EN L140/63-87

Convery, F.J. and L. Redmond. (2007). "Market and Price Developments in the European Union Emissions Trading Scheme.” Review of Environmental Economics and Policy 1:88-111.

Crocker, T.D. (1966). “The Structuring of Atmospheric Pollution Control Systems”. In: Wolozin, H. (Ed.), The Economics of Air Pollution. New York: W.W. Norton and Company, Inc.

Dahlman, C.J. (1979). “The Problem of Externality.” Journal of Law and Economics 22:141-162.

Dales, J. (1968). Pollution, Property and Prices. Toronto: University Press.

Ellerman, A. Denny, "From Autarkic to Market-based Compliance: Learning from our Mistakes," in Kosobud, Richard F. (ed.), Emissions Trading: Environmental Policy's New Approach, John Wiley \& Sons, Inc., 2000, pp. 190-215.

Ellerman, A.D. (2008). “The EU Emission Trading Scheme: A Prototype Global System?” Discussion Paper 2008-02, Harvard Project on International Climate Agreements, Cambridge, Massachusetts.

Ellerman, A.D. and B.K. Buchner. (2007). “The European Union Emissions Trading Scheme: Origins, Allocation, and Early Results.” Review of Environmental Economics and Policy 1:66-87.

Ellerman, A.D. and B.K. Buchner. (2008). "Over-Allocation or Abatement? A Preliminary Analysis of the EU ETS Based on the 2005-06 Emissions Data.” Environmental and Resource Economics 41:267287.

Ellerman, A.D., P.L. Joskow and D. Harrison Jr., (2003). "Emissions Trading in the U.S.: Experience, Lessons and Considerations for Greenhouse Gases.” PEW Center for Global Climate Change, Arlington VA.

Ellerman, A.D., P.L. Joskow, R. Schmalensee, J.P. Montero, and E.M. Bailey. (2000). Markets for Clean Air: The U.S. Acid Rain Program. New York: Cambridge University Press. 
Ellerman, A.D. and J.P. Montero (2007). "The Efficiency and Robustness of Allowance Banking in the U.S. Acid Rain Program.” The Energy Journal 28:47-71.

Eshel, D.M.D. (2005). “Optimal Allocation of Tradable Pollution Rights and Market Structures.” Journal of Regulatory Economics 28:205-223.

Farrell, A. (2001). "Multi-lateral Emission Trading: Lessons from Inter-state NOx control in the United States.” Energy Policy 29:1061-1072.

Farrell, A. (2003). "Temporal Hotspots in Emission Trading Programs: Evidence from the Ozone-Transport Commission's NOx Budget.” Paper presented at conference on Market Mechanisms and Incentives: Applications to Environmental Policy, Washington, D.C.

Farrell, A., R. Carter, and R. Raufer. (1999). "The NOx Budget: Market-based Control of Tropospheric Ozone in the Northeastern United States.” Resource and Energy Economics 21:103-124.

Farrell, A.E. and L.B Lave. (2004). “Emission Trading and Public Health.” Annual Review of Public Health 25:119-138.

Fischer, C. (2001). "Rebating Environmental Policy Revenues: Output-Based Allocations and Tradable Performance Standards.” Washington, D.C.: Resources for the Future.

Fischer, C., and A.K. Fox. (2007). “Output-Based Allocation of Emissions Permits for Mitigating Tax and Trade Interactions.” Land Economics 83:575-599.

Fischer, Carolyn, and Alan K. Fox. 2009. Combining Rebates with Carbon Taxes: Optimal Strategies for Coping with Emissions Leakage and Tax Interactions. RFF Discussion Paper No. 09-12, Washington, DC: Resources for the Future.

Ford, M, A. Gurney, C. Tulloh, T. McInnis, R. Mi and H. Ahammad. (2009). “Agriculture and the Carbon Pollution Reduction Scheme (CPRS): Economic Issues and Implications.” Issues \& Insights 09.2, ABARE Project.

Fowlie, M. and J.M. Perloff, (2008). Distributing Pollution Rights in Cap-and-Trade Programs: Are Outcomes Independent of Allocation? Department of Agricultural and Resource Economics, UC Berkeley.

Fullerton, D., S.P. McDermott, and J.P. Caulkins. (1997). "Sulfer Dioxide Compliance of a Regulated Utility.” Journal of Environmental Economics and Management 34:32-53.

Gangadharan, L. (2000). “Transaction Costs in Pollution Markets: An Empirical Study.” Land Economics 76:601-614.

Gangadharan, L. (2004). "Analysis of Prices in Tradable Emission Markets: An Empirical Study of the Regional Clean Air Incentives Market in Los Angeles.” Applied Economics 36:1569-1582.

Goulder, L.H. and I.W.H. Parry. (2008). "Instrument Choice in Environmental Policy." Review of Environmental Economics and Policy 2(2).

Hahn, R.W. (1984). “Market Power and Transferable Property Rights.” Quarterly Journal of Economics 99:753-765. 
Hahn, R.W. and G.L. Hester (1989). “Marketable Permits: Lessons for Theory and Practice.” Ecology Law Quarterly 16:361-406.

Hahn, R.W. and A.M. McGartland. (1989). "The Political Economy of Instrument Choice: An Examination of the U.S. Role in Implementing the Montreal Protocol.” Northwestern University Law Review 83:592-611.

Hahn, R.W., and R.G. Noll. (1983). "Barriers to Implementing Tradable Air Pollution Permits: Problems of Regulatory Interactions.” Yale Journal on Regulation 1:63-91.

Hahn, R.W., and R.N. Stavins. (1999). What has the Kyoto Protocol Wrought? Washington, D.C.: American Enterprise Institute, Washington, D.C.

Haites, E. and T. Hussain. (2000). “The Changing Climate for Emissions Trading in Canada.” Review of the European Community and International Environmental Law 9:264-275.

Harrison Jr., D. (2003). "Ex Post Evaluation of the Reclaim Emissions Trading Program for the Los Angeles Air Basin.” Draft for National Policies Division, OECD Environment Directorate.

Hazlett, T. (2009). “Ronald H. Coase.” In: Cohen, L. and J. Wright (Eds.), Pioneers in Law and Economics. Northampton, Massachusetts: Edward Elgar.

Houser, T., R. Bradley, B. Childs, J. Werksman, and R. Heilmayr. (2008). Leveling the Playing Field: International Competition and U.S. Climate Policy Design. Washington, D.C.: Peterson Institute For International Economics and World Resources Institute.

Johnson, S.L. and D.M. Pekelney. (1996). "Economic Assessment of the Regional Clean Air Incentives Market: A New Emissions Trading Program for Los Angeles.” Land Economics 72: 277-297.

Joskow, P.L. and R. Schmalensee. (1998). “The Political Economy of Market-based Environmental Policy: The U.S. Acid Rain Program.” Journal of Law and Economics 41:81-135.

Joskow, P.L., R. Schmalensee and E.M. Bailey. (1998). “The Market for Sulfur Dioxide Emissions.” The American Economic Review 88:669-685.

Jotzo, F. and R. Betz. (2009). “Linking the Australian Emissions Trading Scheme.” Working Paper, forthcoming in Climate Policy.

Kahneman, D., J. L. Knetsch, and R.H. Thaler. (1990). "Experimental Tests of the Endowment Effect and the Coase Theorem.” Journal of Political Economy 98:1325-1348.

Kahneman, D., J.L. Knetsch, and R.H. Thaler. (1991). “Anomalies: The Endowment Effect, Loss Aversion, and Status Quo Bias.” Journal of Economic Perspectives 5:193-206.

Kerr, S. (2009). "Comments to Select Committee". Invited Independent Specialist Advice on the Climate Change Response (Moderated Emissions Trading) Amendment Bill.

Kerr, S. and D. Mare. (1998). “Transaction Costs and Tradable Permit Markets: The United States Lead Phasedown.” Manuscript, Motu Economic and Public Policy Research, New Zealand. 
Kerr, S. and R.G. Newell. (2003). "Policy-Induced Technology Adoption: Evidence from the U.S. Lead Phasedown." The Journal of Industrial Economics 51:317-343.

Kerr, S. and W. Zhang. (2009). "Allocation of New Zealand Units within Agriculture in the New Zealand Emissions Trading System.” Motu Working Paper 09-16.

Kolodziej, M. and I. S. Wing. "The Regional Greenhouse Gas Initiative: Emission Leakage and the Effectiveness of Interstate Border Adjustments.” Working Paper, Boston University.

Krupnick, A., W. Oates, and E. Van De Verg. (1983). “On Marketable Air-Pollution Permits: The Case for a System of Pollution Offsets.” Journal of Environmental Economics and Management 10: 233-247.

Liski, M. (2001). “Thin Versus Thick CO2 Market.” Journal of Environmental Economics and Management 41:295-311.

Liski, M. and J.P. Montero. (2009). "Market Power in an Exhaustible Resource Market: The Case of Storable Pollution Permits.” Discussion Paper No. 276, Helsinki Center of Economic Research, forthcoming in the Economic Journal.

Malik, A. (2002). "Further Results on Permit Markets with Market Power and Cheating." Journal of Environmental Economics and Management 44:371-390.

Malueg, D.A. (1990). "Welfare Consequences of Emission Credit Trading Programs." Journal of Environmental Economics and Management 18:66-77.

Malueg, D.A. and A.J. Yates, (2009). "Bilateral Oligopoly, Private Information, and Pollution Permit Markets.” Environmental \& Resource Economics 43:553-572.

May, P. (2005). “Compliance Motivations: Perspectives of Farmers, Homebuilders, and Marine Facilities.” Law and Policy 27:317-347.

Misiolek, W.S. and H.W. Elder. (1989). “Exclusionary Manipulation of Markets for Pollution Rights.” Journal of Environmental Economics and Management 16:156-166.

Montero, J.P. (1998). “Marketable Pollution Permits with Uncertainty and Transaction Costs.” Resource and Energy Economics 20:27-50.

Montgomery, D.W. (1972). “Markets in Licenses and Efficient Pollution Control Programs.” Journal of Economic Theory 5, 395.

Murphy, J.J. and J.K. Stranlund. (2005). "A Laboratory Investigation of Compliance Behavior under Tradable Emissions Rights: Implications for Targeted Enforcement.” Working Paper 2005-1, University of Massachusetts Amherst, Department of Resource Economics. Forthcoming in the Journal of Environmental Economics and Management.

Nash, J.R. and R.L. Revesz. (2001). "Markets and Geography: Designing Marketable Permit Schemes To Control Local and Regional Pollutants.” Ecology Law Quarterly 28:569-662.

Oates, W.E. and D.L. Strassmann. (1984). “Effluent Fees and Market Structure.” Journal of Public Economics 24:29-46. 
Pan, H. and D.V. Regemortor. (2004). “The Costs and Benefits of Early Action before Kyoto Compliance.” Energy Policy 32: 1477-1486.

Parker, C. (2006). “The 'Compliance' Trap: The Moral Message in Responsive Regulatory Enforcement.” Law and Society Review 40:591-622.

Peeters, M. and S. Welshaar. (2009). "Exploring Uncertainties in the EU ETS: 'Learning by Doing' Continues Beyond 2012.” The Carbon and Climate Law Review 3:88-101.

Pigou, A.C. (1920). The Economics of Welfare. London: Macmillan.

Reguant, M. and A.D. Ellerman. (2008). "Grandfathering and the Endowment Effect: an Assessment in the Context of the Spanish National Allocation Plan.” Center for Energy and Environmental Policy Research, Cambridge, Massachusetts.

RGGI CO2 Allowance Tracking System. (2010). Transaction Price Report. Available at: https://rggi-coats.org/eats/rggi/index.cfm?fuseaction=reportsv2.price_rpt\&clearfuseattribs=true.

Saloner, G. and A. Shepard. (1995). "Adoption of Technologies with Network Effects: An Empirical Examination of the Adoption of Automated Teller Machines.” Rand Journal of Economics 26:479501.

Samuelson, W., and R. Zeckhauser. (1988). “Status Quo Bias in Decision Making.” Journal of Risk and Uncertainty 1:7-59.

Sartzetakis, E.S. (2004). “On the Efficiency of Competitive Markets for Emission Permits.” Environmental and Resource Economics 27:1-19.

Schmalensee, R., P.L. Joskow, A.D. Ellerman, J.P. Montero and E.M. Bailey. (1998). “An Interim Evaluation of Sulfur Dioxide Emissions Trading.” Journal of Economic Perspective 12:53-68.

Schwartz, S. (2007). “Market Power Effects on Market Equilibrium in Ambient Permit Markets.” B. E. Journal of Economic Analysis and Policy 7: Article 13.

Stavins, R.N. (1995). “Transaction Costs and Tradeable Permits.” Journal of Environmental Economics and Management 29:133-148.

Stavins, R.N. (1998). "What Can We Learn from the Grand Policy Experiment? Lessons from $\mathrm{SO}_{2}$ Allowance Trading.” Journal of Economic Perspectives 12:69-88.

Stavins, R.N. (2003). “Experience with Market-Based Environmental Policy Instruments.” Handbook of Environmental Economics 1: 355-435.

Stavins, R.N., (2007). "Market-Based Environmental Policies: What Can We Learn From U.S. Experience (and Related Research)?” Moving to Markets in Environmental Regulation: Lessons from Twenty Years of Experience, eds. Jody Freeman and Charles Kolstad, pp. 19-47. New York: Oxford University Press.

Stavins, R.N. (2008). “A Meaningful U.S. Cap-And-Trade System To Address Global Climate Change.” Harvard Environmental Law Review 32:293-371. 
Stigler, G.J. (1988). Memoirs of an Unregulated Economist. New York: Basic Books.

Swinton, J.R. (2002). "The Potential for Cost Savings in the Sulfur Dioxide Allowance Market: Empirical Evidence from Florida.” Land Economics 78:390-404.

Thaler, R. (1980). “Toward a Positive Theory of Consumer Choice.” Journal of Economic Behavior and Organization 1:39-60.

Tietenberg, T. H. (1985). Emissions Trading: An Exercise in Reforming Pollution Policy. Washington, D.C.: Resources for the Future.

Tschirhart, J.T. (1984). “Transferable Discharge Permits and Profit-Maximizing Behavior.” In: Crocker, T.D. (Ed.), Economic Perspectives on Acid Deposition Control. Stoneham, Massachusetts: Butterworth Publishers.

U.S. Environmental Protection Agency, Office of Policy Analysis. (1985). "Costs and Benefits of Reducing Lead in Gasoline, Final Regulatory Impact Analysis.”

Weitzman, H. (2009). "RGGI: Mandatory Scheme Makes Modest Gains in Northeast.” Financial Times, December 13.

Westskog, H. (1996). “Market Power in a System of Tradable $\mathrm{CO}_{2}$ Quotas.” Energy Journal 17: 85-103.

Weyant, J. and J. Hill. (1999). “Introduction and Overview to Special Issue.” In: The Costs of the Kyoto Protocol: A Multi-Model Evaluation. The Energy Journal Special Issue:VII-XLIV.

Williamson, O. (1963). “Managerial Discretion and Business Behavior.” American Economic Review 53:1032-1057. 